\title{
AVIAN DIVERSITY ALONG A PRECIPITATION GRADIENT IN SOUTHERN AFRICA
}

\author{
G. Kopij \\ Department of Integrated Environmental Science \\ Ogongo Campus University of Namibia \\ Private Bag 5520 Oshakati NAMIBIA \\ E-mail:g.kopij@unam.na \\ G. Kopij (https://orcid.org/ 0000-0001-7614-1983)
}

Avian Diversity along a Precipitation Gradient in Southern Africa. Kopij, G. - In April 2013, a transect c. $1100 \mathrm{~km}$ long with 100 points arranged in 5 sections was designed in northern Namibia between Ruacana Watefall (W) and Kongola (E) to study avian diversity in relation to gradual changes in precipitation (c. $350 \mathrm{~mm}$ in $\mathrm{W}$ to c. $600 \mathrm{~mm}$ in E). In total, 81 bird species were recorded in all 100 points, but in particular section, the numbers were low, ranging from 22 to 38 species. In overall, the most frequent and most numerous (dominant) were the following species: Cape Turtle Dove, Blue Waxbill Grey-headed Sparrow, Laughing Dove and Fork-tailed Drongo. Together they comprised $42.2 \%$ of all individuals recorded. All of them, except for the Fork-tailed Drongo, were granivores. Only nine species were recorded in ten or more points. Besides the above-mentioned dominant species, the following other were in this group: Black-chested Prinia, Black-throated Canary, Pied Crow and White-browed Scrub Robin. In particular section the number of dominant species ranged from 5 to 7 , without a gradient. Two species, the Cape Turtle Dove and Blue Waxbill, remained dominant in all five sections. The Laughing Dove and Fork-tailed Drongo - in four sections, and the Grey-headed Sparrow - in three sections. Although, no gradient in species diversity, evenness, and dominance structure was recorded, significant differences between two most western and two most eastern sections were apparent. Two species were more frequent and numerous in the eastern than in the western sections: White-browed Scrub Robin and Cape Turtle Dove; while the following species were more frequent and numerous in the western than the eastern sections: African Palm Swift, Black-chested Prinia, Black-throated Canary, Blue Waxbill, Greyheaded Sparrow and Pied Crow.

Key words: community ecology, ecological gradient, point count method. 


\section{Introduction}

Ecological gradients are quantified patterns describing the ways of change of some ecological parameters, e. g. biodiversity, change with latitude, altitude, humidity, air pressure, air temperature etc. They are among the most widely recognised patterns in ecology and may exist almost in each imaginable ecosystem in the world, and may refer to almost all ecological factors (Smith, 1996). However, the best known are longitudinal, altitudinal and precipitation gradients. They are usually linked to gradual changes in vegetation, and these in turn are caused by gradual changes in precipitation and air temperature (Begon et al., 2006). It is well known that, biodiversity is, in general, increasing gradually southwards in northern hemisphere, and northwards in the southern hemisphere; and it is decreasing with the increase of the altitude in most places in the world (Smith, 1996). Less obvious are such changes along a precipitation gradient (e. g. Kopij, 2006, 2014 a). So, in this paper, the precipitation gradient was investigated in the central part of the southern African subcontinent. A subject of this investigation was avian diversity. Since precipitation increases eastwards in central part of southern Africa (Mendesohn et al., 2009), a gradient in avian diversity was also expected.

\section{Methods}

The point count method was employed in this study (Bibby et al., 2012; Sutherland, 1996). Points were arranged along a transect running along a highway in extreme northern part of Namibia. The transect starting point was near Ruacana Waterfall in the Kunene Region, and the ending point was in Kongola in the Zambezi Region. Five sections (A, B, C, D, and E) were designed in the transect, and in each section 20 points were located. There were therefore together 100 points. Points were separated by a distance of $5 \mathrm{~km}$ in section A-D, and by $10 \mathrm{~km}$ in section E (fig. 1, table 1). All birds seen and/or heard around each such point were recorded. At each point counting lasted about five minutes. Counting was conducted in the morning under sunny and calm conditions. Points were accessed by a car.

The dominance is expressed here as the percentage of the total number of individuals of a given species in relation to the total number of all individuals of all species recorded. The dominant species is defined as that comprising $5 \%$ and more of all individuals of all species recorded, while subdominant - that comprising $2-4.99 \%$. The cumulative dominance is defined as the sum of dominance value of all dominant species. The community dominance index was calculated as follow: $\mathrm{DI}=\left(\mathrm{n}_{1}+\mathrm{n}_{2}\right) / \mathrm{N}$, where $\mathrm{n}_{1}, \mathrm{n}_{2}-$ number of pairs of two most abundant species, $\mathrm{N}-$ total number of pairs of all species.

The following indices were used to characterize the diversity and evenness of the communities:

1) Shannon's diversity index: $\mathrm{H}^{\prime}=-\sum \mathrm{p}_{i} \ln \mathrm{p}_{i}$,

where: $\mathrm{p}_{i}$ is the proportion of individuals belonging to the $i$ th species;

2) Simpson's diversity index: $\mathrm{D}=\left(\left(\sum \mathrm{n}(\mathrm{n}-1)\right) / \mathrm{N}(\mathrm{N}-1)\right.$,

where: $\mathrm{n}-$ total number of individuals belonging to a given species, $\mathrm{N}-$ total number of breeding pairs of all species;

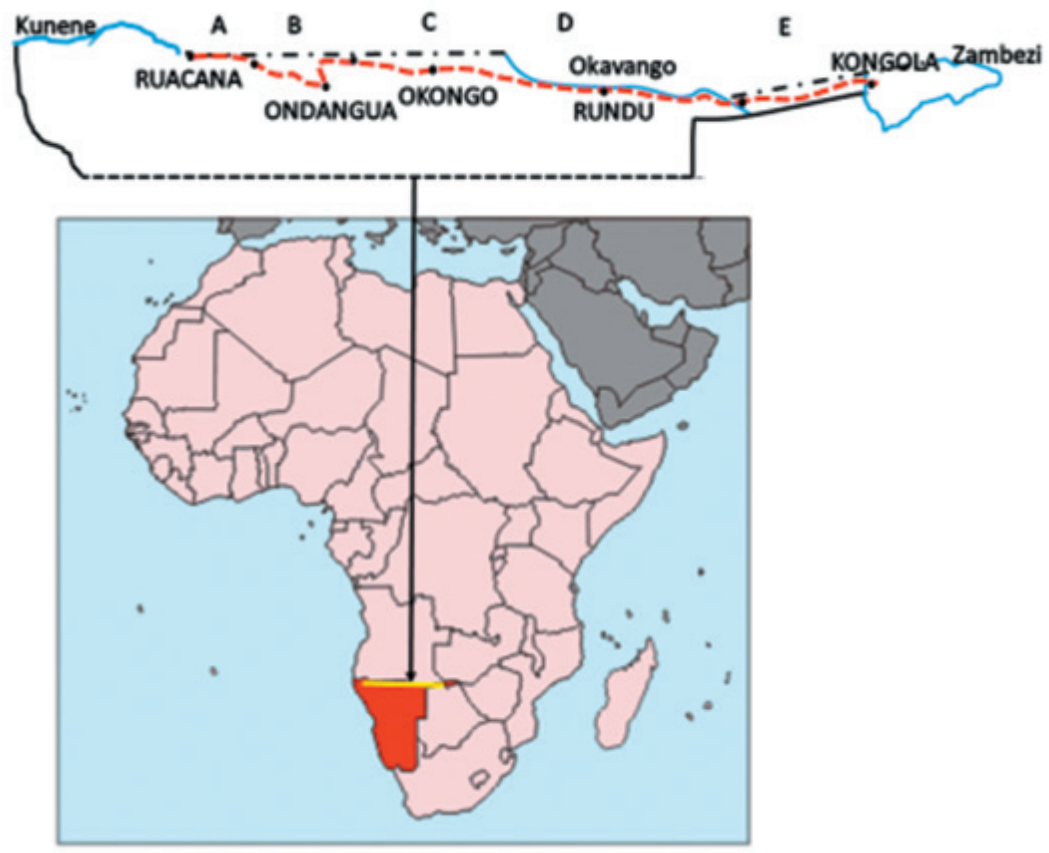

Fig. 1. Location of the transect (broken red line in the map above, yellow line in the map below). 
Table 1. The division of the latitudinal transect into sections, their length, number of count points and date of counts

\begin{tabular}{c|l|c|c|c|c}
\hline No & \multicolumn{1}{c|}{ Section } & $\begin{array}{c}\text { Mean annual } \\
\text { precipitation, } \mathrm{mm}\end{array}$ & $\begin{array}{c}\text { Length, } \\
\mathrm{km}\end{array}$ & $\begin{array}{c}\text { No. of } \\
\text { points }\end{array}$ & Data of counts \\
\hline A & Ruacana Waterfall-Outapi & 350 & 100 & 20 & 13.04 .2013 \\
B & Ogongo-Ondangua & 450 & 100 & 20 & 15.04 .2013 \\
C & Eenhana-Mpingu Vlei & 500 & 100 & 20 & 22.04 .2013 \\
D & Rundu-Kaukuwa & 550 & 100 & 20 & 08.04 .2013 \\
E & Divindu-Kongola & 600 & 200 & 20 & 08.04 .2013 \\
\hline
\end{tabular}

3) Pielou's evenness index: $J^{\prime}=\left(-\sum \mathrm{p}_{i} \ln \mathrm{p}_{i}\right) / \ln \mathrm{S}$,

where $\mathrm{p}_{i}$ is the proportion of individuals belonging to the $i$ th species; $\mathrm{S}-$ total number of species. J' varies between 0 and 1 . The less variation between species in a community, the higher J' is.

Similarity among avian communities (study plots) was investigated using the Sörensen's Coefficient: $\mathrm{I}=2 \mathrm{C} / \mathrm{A}+\mathrm{B}$, where $\mathrm{A}-$ the number of bird species in one plot, $\mathrm{B}-$ the number of bird species in another plot, $\mathrm{C}$ - the number of bird species common to both plots.

Systematics and nomenclature of bird species follow Hockey et al. (2005). Scientific names of all bird species are listed in Appendix 1.

\section{Results}

A total of 81 bird species were recorded in all 100 points. In the particular section, the numbers were, however, much lower, ranging from 22 to 38 species (table 2). In overall, the most frequent and most numerous (dominant) were the following species: Cape Turtle Dove (recorded in $40 \%$ of points, and comprising $11.7 \%$ of all individuals recorded), Blue Waxbill (47 \% vs. $9.3 \%$ ), Grey-headed Sparrow (38 \% vs. $8.3 \%$ ), Laughing Dove (37 \% vs. $7.6 \%)$ and Fork-tailed Drongo (29 \% vs. $5.3 \%)$. Together they comprised $42.2 \%$ of all individuals recorded. All of them, except for the Fork-tailed Drongo, were granivores. Only nine species were recorded in ten or more points. In addition to the above-mentioned dominant species, the following other were in this group: Black-chested Prinia, Blackthroated Canary, Pied Crow and White-browed Scrub Robin (App. 1).

In the particular section, the number of dominant species ranged from 5 to 7 , without a gradient. Two species, the Cape Turtle Dove and Blue Waxbill, remained dominant in all five sections. The Laughing Dove and Fork-tailed Drongo - in four sections, and the Grey-headed Sparrow - in three sections. Nine other species were recorded as dominant only in two (Black-throated Canary, White-browed Scrub Robin) or in one section (Blackchested Prinia, African Palm Swift, Cattle Egret, Pied Crow, Rattling Cisticola, Red-billed Hornbill and Red-eyed Dove) (App. 1). However, the cumulative dominance has decrease eastwards, while no gradient was recorded in the community dominance index (table 3 ).

The study suggests that there is an eastward increase in the population density of the following species: Brubru, Burchell's Starling, Emerald-spotted Dove, Red-billed Oxpecker, Ground Hornbill, Schalow's Turaco, Red-eyed Dove, Magpie Shrike, Southern Black Tit,

Table 2. Characterisation of breeding bird community in five sub-transects (sections) of a latitudinal transect in northern Namibia

\begin{tabular}{|c|c|c|c|c|c|c|}
\hline Parameter & A & B & $\mathrm{C}$ & $\mathrm{D}$ & $\mathrm{E}$ & Total \\
\hline \multicolumn{7}{|c|}{ Number of species and pairs } \\
\hline Number of species & 30 & 32 & 22 & 38 & 27 & 81 \\
\hline Number of breeding pairs & 120 & 157 & 74 & 123 & 88 & 591 \\
\hline \multicolumn{7}{|c|}{ Dominance } \\
\hline Number of dominant species & 6 & 7 & 5 & 6 & 6 & 5 \\
\hline Cumulative dominance (\%) & 57.0 & 62.7 & 67.8 & 64.8 & 58.2 & 42.2 \\
\hline Community dominance (DI) & 0.28 & 0.28 & 0.65 & 0.24 & 0.44 & 0.21 \\
\hline \multicolumn{7}{|c|}{ Indices } \\
\hline Shannon's Diversity Index (H') & 2.93 & 2.94 & 2.55 & 3.53 & 2.84 & 2.14 \\
\hline Pielou's Evenness Index (J’) & 0.86 & 0.85 & 0.82 & 0.97 & 0.86 & 0.49 \\
\hline
\end{tabular}




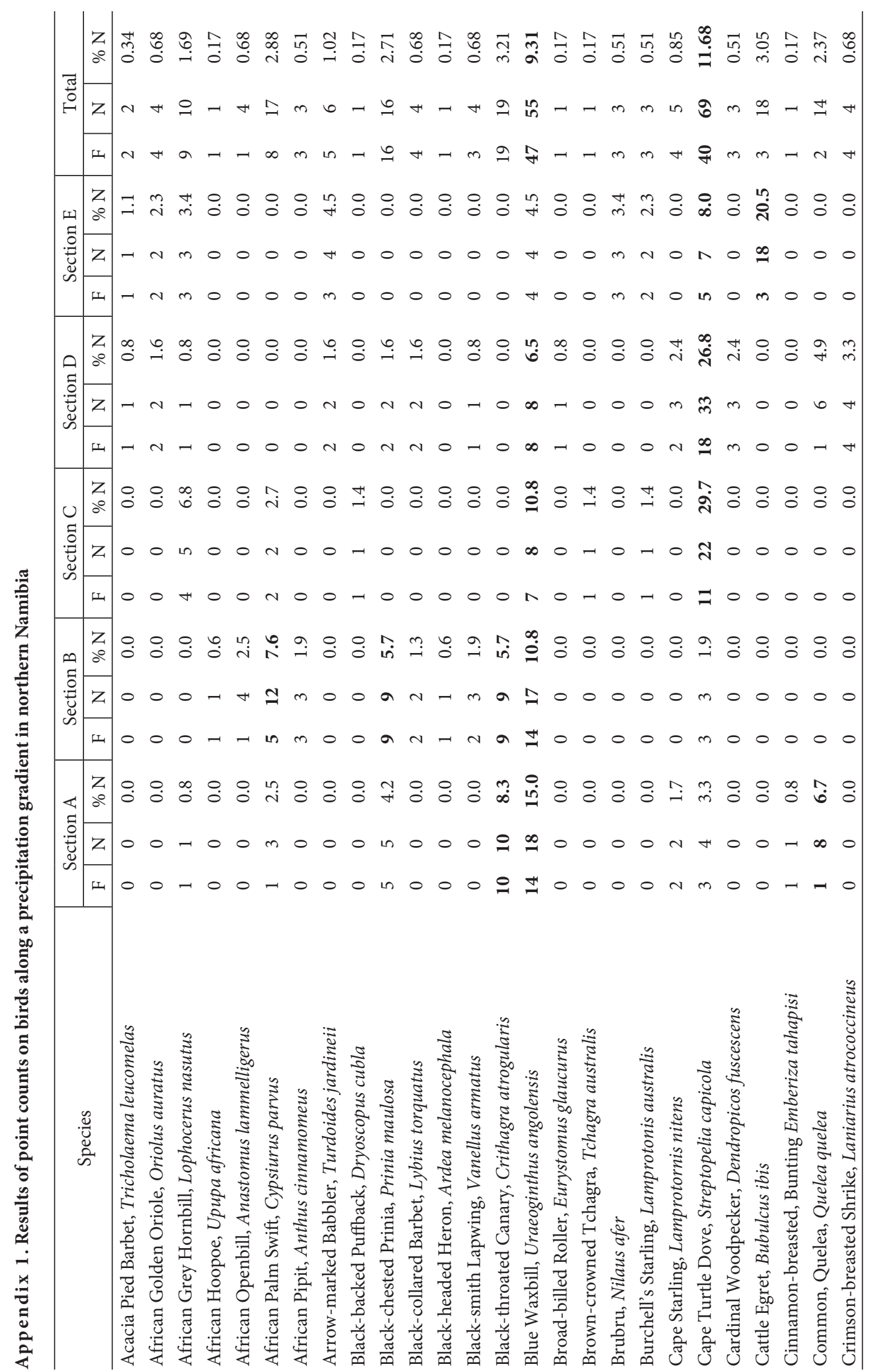




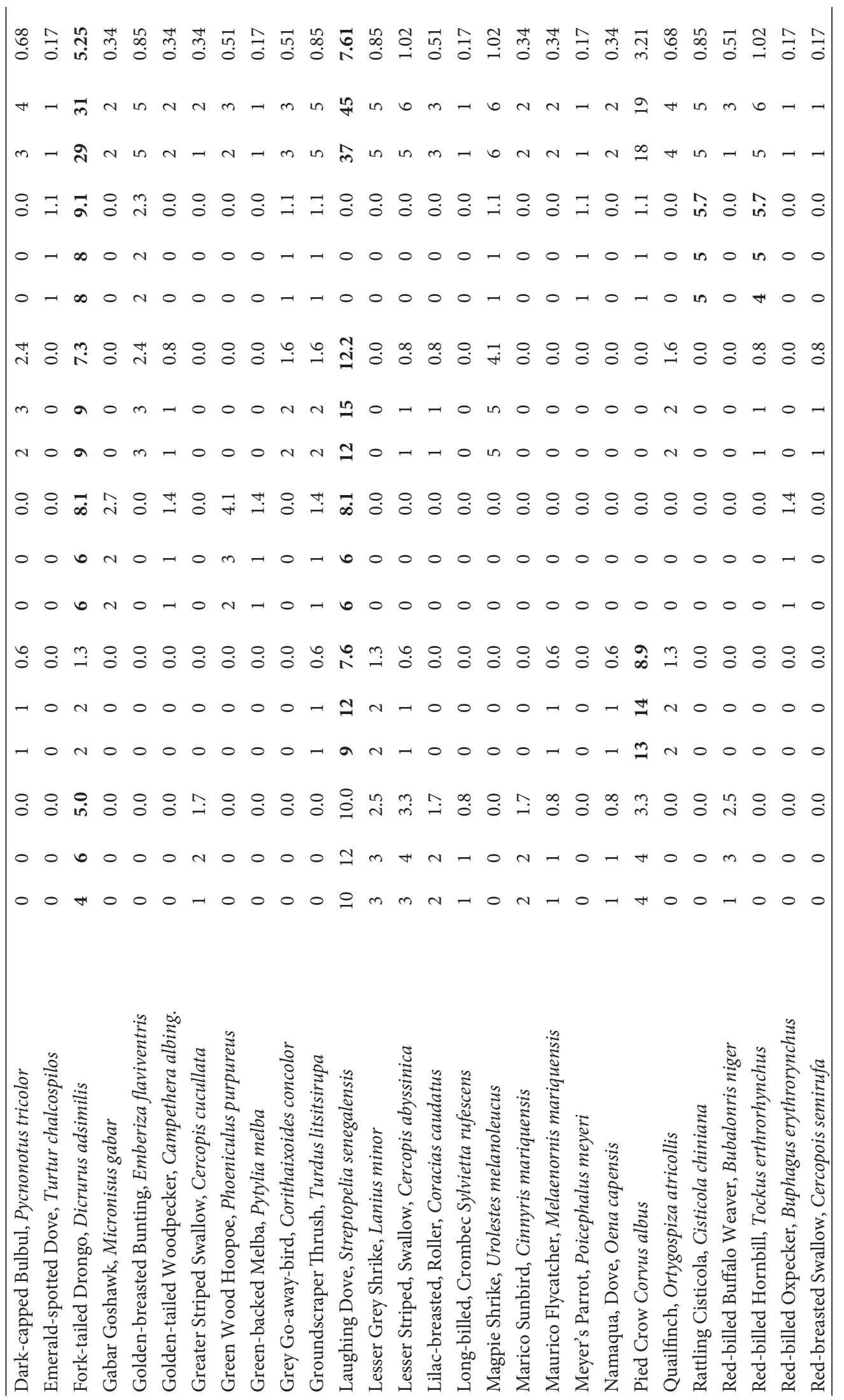




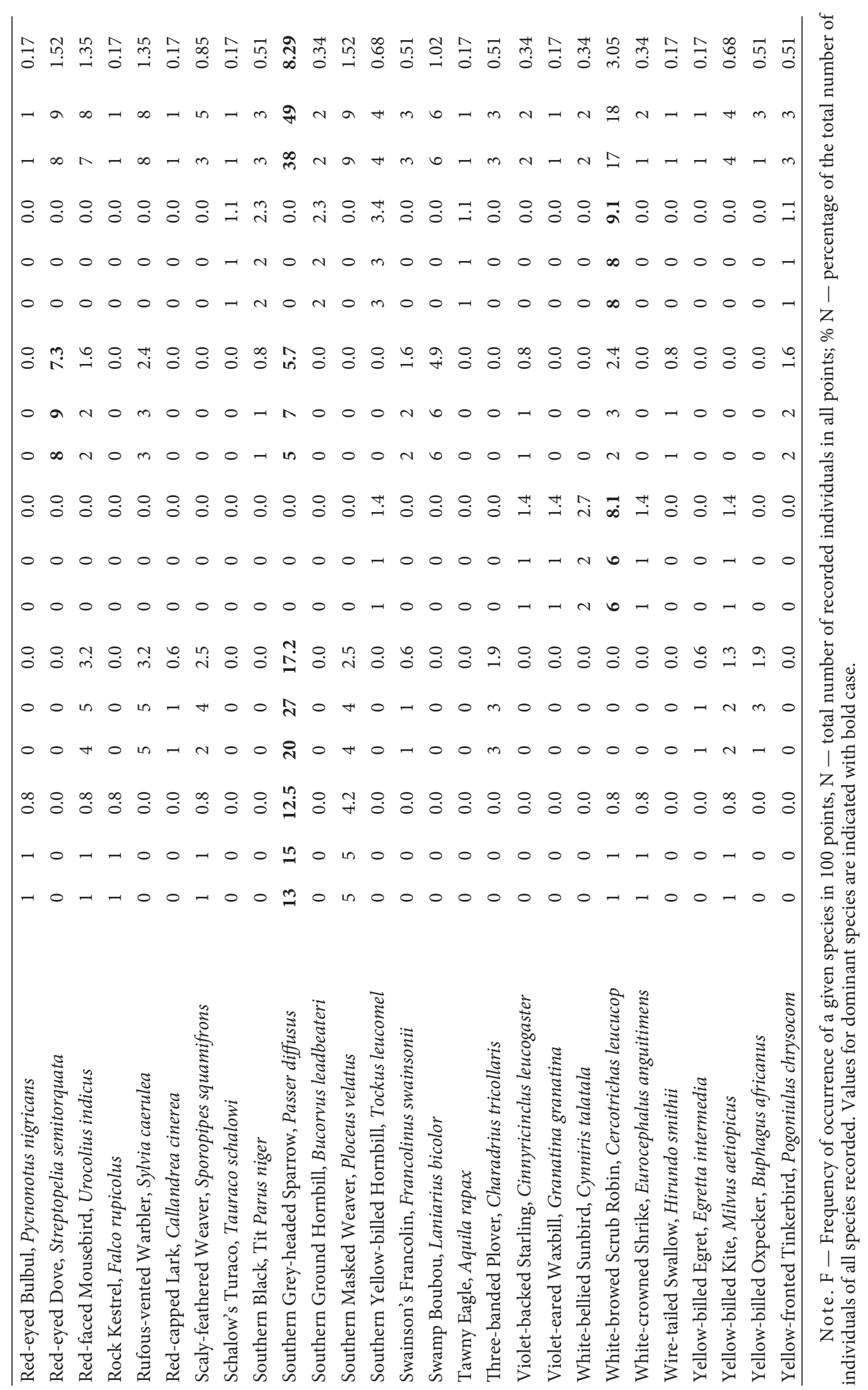


Table 3. Difference in the frequency of occurrence and in the numerical percentage in bird species between eastern $(D, E)$ and western $(A, B)$ parts of Namibia

\begin{tabular}{l|c|c|c|c}
\hline \multirow{2}{*}{\multicolumn{1}{c|}{ Species }} & \multicolumn{2}{c|}{$\begin{array}{c}\text { Based on frequency of } \\
\text { records }\end{array}$} & \multicolumn{2}{c}{$\begin{array}{c}\text { Based on number of indi- } \\
\text { viduals recorded }\end{array}$} \\
\cline { 2 - 5 } & $x^{2}$-value & $\begin{array}{c}\text { Level of sig- } \\
\text { nificance }\end{array}$ & $x^{2}$-value & $\begin{array}{c}\text { Level of sig- } \\
\text { nificance }\end{array}$ \\
\hline African Palm Swift & $\mathrm{E}<5$ & - & 15 & 0.01 \\
Black-chested Prinia & 9 & 0.01 & 9 & 0.01 \\
Black-throated Canary & 19 & 0.01 & 19 & 0.01 \\
Blue Waxbill & 6.4 & 0.05 & 11.2 & 0.01 \\
Cape Turtle Dove & 9 & 0.01 & 23.2 & 0.01 \\
Cattle Egret & $\mathrm{E}<5$ & - & 9 & 0.01 \\
Fork-tailed Drongo & 5.2 & 0.05 & 1.6 & $>0.05$ \\
Grey-headed Sparrow & 20.6 & 0.01 & 25 & 0.01 \\
Laughing Dove & 1.6 & $>0.05$ & 2.1 & $>0.05$ \\
Pied Crow & 14.2 & 0.01 & 15.2 & 0.01 \\
Red-billed Quelea & $\mathrm{E}<5$ & - & 0.1 & $>0.05$ \\
White-browed Scrub Robin & 7.2 & 0.01 & 8.3 & 0.01 \\
Total & 2.1 & $>0.05$ & 2.6 & $>0.05$ \\
\hline
\end{tabular}

Note. All species listed occur commonly both in the eastern $(D, E)$ and the western $(A, B)$ part of the transect.

White-browed Scrub Robin, Golden-breasted Bunting, Arrow-marked Babbler, African Golden Oriole and Yellow-fronted Tinkerbird. The data suggest also westward increase in the population densities of the Yellow-billed Oxpecker, Namaqua Dove, Lesser Striped Swallow, Scaly-feathered Finch and Grey-headed Sparrow (App. 1).

Contrary to expectation, no gradient was recorded in the number of bird species, neither in the number of individuals recorded. Also no gradient was recorded in the Diversity Index and the Evenness Index (table 3).

Although, no gradient in species diversity, evenness, and dominance structure was recorded, significant differences between two most western and two most eastern sections were apparent. Two species were more frequent and numerous in the eastern than in the western sections: White-browed Scrub Robin and Cape Turtle Dove; while the following species were more frequent and numerous in the western than the eastern sections: African Palm Swift, Black-chested Prinia, Black-throated Canary, Blue Waxbill, Grey-headed Sparrow and Pied Crow. All the differences were statistically significant (table 3).

As expected, the most similar were bordering sections laying at the two ends of the transect: A vs. B, and D vs. E; the most dissimilar - sections laying at opposite ends of the transect: A vs. E, and B vs. E (table 4).

\section{Discussion}

The point count method employed in this study could underestimate some elusive, not active, and silent species, e. g. tits (Paridae), finches (Estrildidae) or korhaans (Otidae). Of cause, nocturnal birds were omitted in this study altogether. The points were not arranged near lakes or marshlands, so also species associated with these habitats are omitted here. The point count method employed in this study enables, however, a rough estimate of abundance of common and easily detected species, such as doves, shrikes or drongos.

In the northern hemisphere a precipitation and temperature gradients overlap to large extent with the latitudinal gradient. In some tropical regions of the world, e. g. in southern Africa, such overlap does not exist, and more often such changes occur along the same latitude, i.e. from the east to the west. Such situation was also confirmed in this study.

Table 4. Sorensen index of similarity between particular sections (A-E) of the transect

\begin{tabular}{c|c|c|c|c|c}
\hline & $\mathrm{A}$ & $\mathrm{B}$ & $\mathrm{C}$ & $\mathrm{D}$ & $\mathrm{E}$ \\
\hline $\mathrm{A}$ & $\mathrm{x}$ & 0.55 & 0.35 & 0.44 & 0.18 \\
$\mathrm{~B}$ & & $\mathrm{X}$ & 0.26 & 0.43 & 0.17 \\
$\mathrm{C}$ & & & $\mathrm{x}$ & 0.30 & 0.33 \\
$\mathrm{D}$ & & & & $\mathrm{x}$ & 0.46 \\
$\mathrm{E}$ & & & & & $\mathrm{x}$ \\
\hline
\end{tabular}


One of the main assumption about the precipitation biodiversity gradient is that the list of species in a given point is complete. In this, as in most other studies, such assumption was, however, not met. This means that the gradient steepness may, in fact, be more pronounced. Such gradient is also more pronounced in a macro (within a few degrees) than in a micro-scale (within a degree), hence the points were grouped in sections to create macro-scale scenario.

Cape Turtle Dove, Laughing Dove, Grey-headed Sparrow and Blue Waxbill recorded in this study as dominant species are probably the most numerous species in northern $\mathrm{Na}$ mibia at large, in both natural and human-transformed habitats (Kopij, 2014 a, b, 2015 a, b, 2017, 2018 a b, 2019 a, b). Except for the Cape Turtle Dove, they also appear to be good indicators of disturbed land, as they dominate both urbanized and agricultural landscape of Namibia (Kopij, 2014 a, b, 2015 c, 2017, 2018 b, 2019 a, b). Most of them were more numerous in the western than in the eastern sections. It is probably because, granivores, are better adopted to live under savannah (western sections) than woodland (eastern sections) conditions, as savannas produce much more seeds (especially grass seeds) than woodlands (Smith, 1996; Begon et al., 2006).

The western or eastern border of geographical range of some bird species run through north-central Namibia (Hockey et al., 2005), hence these species were common either in the eastern or western sections of the transect, but virtually absent in the opposite ones. The group includes the following 'eastern' species: Magpie Shrike, Schalow's Turaco, Red-billed Oxpecker, Broad-billed Roller, Emerald-spotted Dove, Swamp Boubou, Burchell's Starling. The group of 'western' species includes the Yellow-billed Oxpecker and Red-eyed Bulbul.

\section{References}

Begon, M., Townsend, C. R, Harper, J. L. 2006. Ecology. From Individuals to Ecosystems. $4^{\text {th }}$ ed. Blackwell Publishing.

Bibby, C. J., Burgess N. D., Hill, D. A., Mustoe, S. 2012. Bird Census Techniques, $2^{\text {nd }}$ ed. Academic Press, London.

Hockey, P. A. R., Dean, W. R. J., Ryan, P. G, Maree, S., eds. 2005. Roberts' Birds of Southern Africa. John Voelcker Bird Book Fund, Cape Town.

Kopij, G. 2006. The Structure of Assemblages and Dietary Relationships in Birds in South African Grasslands. Wydawnictwo Akademii Rolniczej we Wrocławiu, Wrocław.

Kopij, G. 2014 a. Avian Assemblages in Urban Habitats in North-central Namibia. International Science \& Technology Journal of Namibia, 3 (1), 64-81.

Kopij, G. 2014 b. Avian communities of a Mixed Mopane-Acacia Savanna in the Cuvelai Drainage System, North-Central Namibia, During the Dry and Wet Season. Vestnik Zoologii, 48 (4), 269-274.

Kopij, G. 2015 a. Avian diversity and assemblages around Ruacana Waterfall, north-western Namibia. International Science \& Technology Journal of Namibia, 5, 85-95.

Kopij, G. 2015 b. Seasonal changes in avian communities in a farmland in the Cuvelei Drainage System, northern Namibia. Ornithological Observations, 6, 73-81.

Kopij, G. 2015 c. Avian diversity along altitudinal gradient in Highveld/Drakensberg grasslands. Vestnik Zoo$\operatorname{logii,} 49$ (2), 451-456.

Kopij, G. 2017. Structure of avian assemblages in Zambezian Baikiaea woodlands, northern Namibia. Zoology \& Ecology, 27 (1), 1-10.

Kopij, G. 2018 a. Avian assemblages of the Western Highlands vegetation in the Kunene Region, north-western Namibia. International Journal of Science \& Technology of Namibia, 11, 99-110.

Kopij, G. 2018 b. Population density, and community structure of birds breeding in Mopane Savanna of the Ogongo Game Park, north-central Namibia. International Journal of Science \& Technology of Namibia, $12,117-134$.

Kopij, G. 2019 a. Population density and structure of birds breeding in an urban habitat dominated by large baobabs (Adansonia digitata), Northern Namibia. Biosystem Diversity, 27, 354-360.

Kopij, G. 2019 b. Structure of avian communities in a mosaic of built-up and semi-natural urbanised habitats in Katima Mulilo town, Namibia. Welwitschia International Journal of Agricultural Sciences, 1, 68-75.

Mendesohn, J., Jarvis, A., Roberts, C., Robertson, T. 2009. Atlas of Namibia. A Portrait of the Land and its People. Sunbird Publishers, Windhoek.

Smith, R. L. 1996. Ecology and Field Biology. $5^{\text {th }}$ ed. Addison-Wesley Longman, Menlo Park (CA, USA).

Sutherland, W. J., ed. 1996. Ecological census techniques. A handbook. Cambridge University Press, Cambridge.

Received 23 June 2020

Accepted 5 January 2021 